Socialist Studies / Études socialistes 7(1/2) Spring/Fall 2011: 238-258

Copyright (C) 2011 The Author(s)

SPECIAL ISSUE ON ORGANIZING FOR AUSTERITY: THE NEOLIBERAL STATE, REGULATING LABOUR AND WORKING CLASS RESISTANCE

\title{
The Fragile Rise of Bourgeois Hegemony and the Neoliberal State in Mexico
}

\section{RICHARD ROMAN and EDUR VELASCO ARREGUI}

Sociology, University of Toronto. Ontario, Canada.

Law and Labour Economics, Universidad Autónoma Metropolitana in Mexico City. Mexico.

\begin{abstract}
The corporate offensive was the main driving force in the neoliberal transformation of Mexico as it was in the United States and Canada. But in Mexico the corporate power bloc had to change the political order to achieve its hegemonic aspirations and desired policy changes. While the top bourgeoisie have been able to achieve more direct control of the state, they have not been able to establish a stable system of domination. The rise of bourgeois hegemony in Mexico is fragile. But the working class has not yet been able to find its voice and break free of the bonds of Mexico's old statelinked unions or state system of labour repression in general. However, the on-going hardships imposed by neoliberalism, the fragile legitimacy of the new political regime, and the surviving popular traditions of revolutionary struggle point to a renewal of a class-based popular fight-back sooner rather than later.
\end{abstract}

\section{Résumé}

L'offensive du patronat a été la force prépondérante derrière la transformation néolibérale du Mexique, comme aux Etats-Unis et au Canada. Mais, au Mexique, le bloc du pouvoir patronal était obligé de transformer l'ordre politique afin de réaliser ses aspirations hégémoniques et la transformations politiques souhaitées. Alors que la haute bourgeoisie a réussi à renforcer son contrôle direct sur l'état, elle n'a pas réussi à établir un système stable de domination. L'ascendance de l'hégémonie bourgeoise au Mexique est fragile. Mais, la classe ouvrière n'a pas encore réussi à trouver sa voix et à briser les chaines des anciens syndicats liés à l'état mexicain ou le système étatique de répression du travail en général. Néanmoins, les difficultés de longue durée imposée

Richard Roman is a member of Socialist Project and the Greater Toronto Workers Assembly. He is also a retired professor of Sociology at the University of Toronto and an Associate Fellow of the Centre for Research on Latin America and the Caribbean, York University, Toronto. Edur Velasco Arregui is an elected representative of university workers on the Federal Board of Conciliation and Arbitration (JFCA), former Secretary-General of SITUAM (Sindicato Independiente de Trabajadores de la Universidad Autónoma Metropolitana / Independent Union of Workers of the Metropolitan Autonomous University), and a Professor of Law and Labour Economics at the Universidad Autónoma Metropolitana in Mexico City.

Richard Roman est membre du 'Socialist Project' et de 'Greater Toronto Workers Assembly'. II est également professeur de sociologie, à la retraite, à l'université de Toronto et un membre associé au Centre for Research on Latin America and the Caribbean, à l'université de York, Toronto. Edur Velasco Arregui est un répresentant élu des employés universitaires sur le Federal Board of Conciliation and Arbitration (JFCA), ancien sécrétaire-général du SITUAM (Sindicato Independiente de Trabajadores de la Universidad Autónoma Metropolitana / Syndicat indépendant des travailleurs de l'université metorpolitain autonome) et professur de droit et d'economie du travail à l' Universidad Autónoma Metropolitana à Mexico City. 
ROMAN and ARREGUI: The Fragile Rise of Bourgeois Hegemony

par le néolibéralisme, la légitimité fragile du nouveau régime politique et les traditions populaires de lutte révolutionnaire qui persistent, suggère la renaissance d'une contreattaque populaire basée sur les classes, plus tôt et non plus tard.

\section{Keywords}

Hegemony; neoliberalism; state; unions; workers

Mots-clés

hégémonie; néoliberalisme; état; syndicats; travailleurs

\section{The Rise of Bourgeois Hegemony}

The Old Regime and the Bourgeoisie

Mexico's one-party presidentialist system, the major role of the state in the economy, and the rhetoric of "revolutionary nationalism" obscured the tremendous power that business had in the old regime as well as its role in bringing about the neoliberal regime and competitive elections. Though there were important differences between the various Mexican presidential regimes of the PRI (Partido Revolucionario Institucional / Institutional Revolutionary Party) in its 70+ years of rule, a constant was the pursuit of national capitalist development. The Mexican Revolution of 1910-1920 produced a regime that combined elements of Bonapartism with elements of corporatism. Though limited to one term after 1928, the President ruled over a system based on the corporatist control of the popular classes incorporated into a state party system. The ruling political elites based their power on the contained and compartmentalized mobilization of popular forces that could offset the power of the domestic oligarchy as well as foreign capital and government. The popular support and legitimacy of the revolutionary regime rested on the promise and practice of major concessions while these concessions, in turn, gave credibility to the legitimating ideology. The extent and the character of these concessions varied from president to president, reaching their most radical peak in the presidency of Lázaro Cárdenas (1934-1940) when major land redistribution was carried out, the foreign owned oil industry was nationalized, and worker and peasant organization was promoted. However the goal of national capitalist development remained primary throughout all these presidencies.

There was a wide spectrum of views within the political elite as to the right mix between social justice and capitalist development but, in general, there was a shared belief that a national capitalist route of 
development was the only viable path. Even those who were socialists, with few exceptions, felt that Mexico had to develop through capitalism. But there was also the widely shared belief that the excesses of capitalism could be contained by an actively interventionist state, that a balance between different class interests could be maintained for the sake of the broader national interest. Capitalist development also provided opportunities for members of the political elite to advance their private interests and to become capitalists themselves.

Beyond opposition to specific governmental policies, the big fear of business was that the great degree of state autonomy, the revolutionary rhetoric of the regime, and the demands of workers and peasants could, as it at times did, lead to major attacks against specific capitalist interests or the interests of capital as a whole. Big business was kept distant from governmental power at the same time that governmental policies generally favoured the interests of big business. Sections of big business, especially the northern business elite centred in Monterrey, persistently and bitterly opposed the strong, relatively autonomous state but cooperated with it in their quest for riches.

Although Big Business was kept away from direct political power, it nevertheless had significant power based on its wealth and control of key sectors of the economy. Capitalists, acting individually or in a coordinated manner, have powerful economic levers that any government has to take into account in shaping policy. Capital flight, the withholding of investment, the relocation of plants, are all potent weapons that can impose powerful constraints or penalties on a government and on its ability to carry out its programs, or even survive.

But the use of this capitalist class power was constrained by divisions within the capitalist class and by the willingness of the political elite to come down fiercely on open criticism of the regime. Thus, while the political elite was constrained by the nature of its goal of capitalist development as well as the strength of some sectors of capital, it also had important leverage that it could use against individual capitalists or sectors of capital. As well as imposing costs and obstacles on difficult companies, it could and did even expropriate some businesses. The use of these levers against individual capitalists would not only give a strong message to other capitalists but these occasional attacks on "selfish" capitalists could contribute to the legitimation of the regime as a "revolutionary nationalist" one. Popular sectors could be mobilized as part of this disciplining and legitimating process. As well, the state actively sought to keep the business class divided, a policy it also carried out among the popular sectors. 
ROMAN and ARREGUI: The Fragile Rise of Bourgeois Hegemony

The power of Big Business grew along with its economic power during the Mexican miracle (1940-1970). But this expansionary phase of Mexico's ISI (Import Substitution Industrialization) period provided significant profits for most sectors of Mexican capital and limited the more extreme anti-regime views within the capitalist class to a minority. The expanded power of business would combine with a series of economic and political crisis to transform the balance of forces within the Mexican bourgeoisie.

The Transition: The Struggle for Hegemony

The growing tensions between the political elites and the Mexican bourgeoisie would come to a head during the presidencies of Luis Echeverría (1970-1976) and José Lopez Portillo (1976-1982) as the regime tried to deal with various political and economic crises in ways that deeply disturbed business. When Luis Echeverría, who had been Secretary of Government (Interior) when the student massacre of 1968 took place, became President in 1970, he sought to regain both his legitimacy and that of the regime by a political liberalization and populist policies of wage increases and state-directed economic development. The government feared that the militancy of the urban-popular protest of the late '60's would spread to the working class. These changes in the regime's strategy - as well as the rise of worker struggles - disrupted the fragile equilibrium between the state elite, big national capital, and the multinationals that had developed during the period of desarrollo estabilizador (stabilized growth model). Key business groups resented the plan to withdraw subsidies and to have more efficient tax collection. They felt threatened by the rise of workers militancy that showed prospects of spilling beyond the terrain of narrowly economic interests.

The sharp rise in business discontent in response to Echeverría's flirtation with populism and the growth of labour militancy in the early 1970 's, led to the formation of the CCE (Consejo Coordinador Empresarial / Business Coordinating Council), the umbrella organization of business that sought to bring together the varied and often discordant voices of business. The key force in the formation of the CCE was the CMHN (Cámara Mexicana de Hombres de Negocios / Mexican Businessmen's Council). The CMHN had been formed in 1962 by twelve of the most powerful businessmen in Mexico who sought to strengthen business influence by forming this highly exclusive and secretive organization with the goal of discretely lobbying and pressuring the government. The CMHN, which now has 36 members, remains the most powerful business group in Mexico. It has provided most 
of the funding for the CCE and many of the CCE's presidents came from the small group of members of the CMHN (Cypher and Delgado Wise 2010; Puga 2004; Schneider 2002). Open business criticism of government policy grew in the '70s but remained limited to criticisms of policy, never extending to the legitimacy of the regime.

The power of business was strengthened by the financial and economic crisis of 1976 which forced Mexico to go to the IMF for help. The leverage of the IMF strengthened the hands of big business and their allies within the government. Thus, the conservative forces in Mexican society, with the aid of international capital and the IMF, were able to defeat the populist flirtation of Echeverría.

The new government of President José Lopez Portillo (1976-1982) sought to restore business confidence and reassure the IMF. Business-state relations warmed when López Portillo made conciliatory gestures to business in the first years of his presidency. The moderate forces in business were strengthened and business retreated from direct policy criticism. Based on the hoped-for revenues from the discovery of vast new oil reserves, the government borrowed massively to finance its "alliance for profits," a policy of promoting and subsidizing profits. While the government's spending spree greatly enriched the wealthy and powerful, it sowed the seeds of Mexico's financial crisis. Mexico's debt crisis both saddled the Mexican people with astronomical public indebtedness and increased the leverage of foreign capital.

Mexico's economic crisis peaked towards the end of Lopez Portillo's presidency as the country faced massive capital flight, the possible bankruptcy of the state, and the financial panic of August 1982. This crisis not only threatened the Mexican state but also the interests of the foreign creditors of Mexico's banks. The President responded by nationalizing the banks (Marois 2008; Cypher 1990, 120-121). The nationalization of the banks by Lopez Portillo in 1982 led to a new political direction for business. The bank nationalization, carried out to protect foreign creditors of Mexican banks, showed both the increased leverage of US capital and the IMF and the tremendous autonomous power of the state to act against the most powerful sections of Mexican capital. The nationalization was accompanied by populist-nationalist rhetoric and elicited a tremendous popular response. Business as a class felt threatened. The strategies of the more radical wings of business gained strength. A consensus was emerging that the regime itself had to be challenged. "Business now had a longer time horizon and its goals were more political and less narrowly instrumental" (Thacker 2000,107). Business now had hegemonic 
ROMAN and ARREGUI: The Fragile Rise of Bourgeois Hegemony

aspirations though, of course, there were still important policy divisions within business on the role of the state in the economy and on free trade. The most powerful sectors of business were for a diminished economic role of the state, the destruction of unions, and an opening of the economy to foreign capital. These sections would be strengthened by the massive privatization of the 1980s and 1990s and would be joined by powerful new sectors created by these very privatization projects. At the same time, those business sectors tied to the domestic market, state subsidies, and state protection from external competition, would be severely weakened.

López Portillo's nationalization of the banks occurred at the very tail end of his presidency. The incoming President, Miguel de la Madrid, was not even consulted. The presidency of de la Madrid can be seen as a transitional presidency to the neoliberal triumph. He first sought to restore business confidence while maintaining the preeminent role of the state in guiding the economy. But Business was not satisfied with this approach and fought hard during the early years of his presidency to shift policy and power more to the neoliberal right, to change tripartite consultations (business, unions and the state) to bipartite (business and the state) and to insulate the government from populist temptations. President de la Madrid carried out measures that greatly strengthened the power of Big Business and affected the internal make-up of the business class. "Many of the new owners of these privatized firms came from 'the ranks of new private financiers that rose to power during the financially volatile 1980s' (Heredia quoted in Thatcher 2000, 116) and the acquisition of these companies fortified the development of the new, independent, financially connected entrepreneurial class" (Thacker 2000,116). The wealth and power of business increased as did the concentration of capital in Mexican society and within the business class.

An important opponent of the neoliberal assault on the state sector was the political-economic elite of the state whose significant privileges and power were based on their commanding positions in state enterprise as well as their simultaneous or sequential roles in the ruling party bureaucracy or government. Their state-based positions required the continuation of a powerful state economic sector. The ideology of "revolutionary nationalism" and the directing role of the state within a capitalist economy fit their interests well. As well, the "charros" sitting atop the large unions in the public sector, who were also intertwined with the ruling party and the state, shared the ideology and interests of the state 
elite in a strong public economic sector. ${ }^{1}$ And workers in this sector often had better jobs and benefits than those in the private sector. As well, important sections of small and middle-sized capital depended on state support and took a positive position towards the government's role in the economy, at least until the late 1960s.

The debate within the government and ruling party over economic policy was rooted in rival hegemonic projects as well as in different models of capitalism, models which had more or less congruency with these rival projects. The hegemony of the old "revolutionary nationalist" historic bloc had to be destroyed for the triumph of the neoliberal historical bloc. The top Mexican capitalists, in alliance with their foreign allies, moved to implement a neoliberal agenda of an export-oriented and open economy and a state that would eliminate the social wage while increasing its coercive power. But along with a different economic direction, the new power bloc - with powerful help from the private owners of the major media - promoted an economic-cultural model that sought to institutionalize a culture of possessive individualism and destroy the remnants of Mexico's communalist cultures that had been given a reprieve by the Mexican Revolution and subsequent decades of revolutionary nationalist hegemony.

Massive privatization destroyed the power base of key sectors of the state elite while creating great wealth and power for new and old sectors of capital. Some of the elites and bureaucrats of state enterprises were able to find soft landings by transferring their skills and energies to the private sector. Others experienced downward mobility. Some of the charros were able to keep control of their reduced membership and have sought to sell their services of labour control to the new private owners. But very few workers in the public transportation and industrial sectors have found soft landings. The massive elimination of public companies, the degradation of working conditions and the collective agreements at those companies that were privatized, the failure to produce new jobs in the regions where state enterprises had been located, have all contributed to the hard landing of most of the former workers in the state transportation

${ }^{1}$ The term "charro" refers to officials of state-linked, corrupt, undemocratic unions. While once an integral part of the ruling party in the one-party regime, they now can best be described as regime-linked, working with whichever of the two neoliberal parties are in power in particular states and nationally, and trying to manoeuvre within the rivalry between these parties to better leverage their bargaining power in terms of preserving their control of their unions. 
ROMAN and ARREGUI: The Fragile Rise of Bourgeois Hegemony

and industrial sectors. It is the residues of this old historic bloc, both its elite members and its mass base, that continue to provide major support for the revival of the modernized "revolutionary nationalism" of Andrés Manuel López Obrador or for the return of the PRI to the presidency, wishfully hoping that it would mean the return of at least some aspects of the economic benefits of the old regime.

\section{The New Regime: Bourgeois Domination without the Consolidation of a Hegemonic Historic Bloc}

The increasingly direct political role of sections of business, mostly through the right-wing PAN (Partido Acción Nacional / National Action Party), led the PRI to seek to give business a more direct presence in the PRI and in the state apparatus. The PRI began to run business candidates against the PANs business candidates, more business people were recruited to work within the state, the more pro-business departments of the state gained power over the more traditionally nationalist departments of the state. The transformation of the state from a Bonapartist capitalist state towards more direct capitalist domination (as in the US and Canada, though still in the political form of a one-party regime) was well underway in the 1980s and would be intensified in the 1990s. In 2000, the first victory of an opposition presidential candidate, the former President of Coca-Cola Mexico, Vicente Fox of the PAN, over the ruling party's candidate was a milestone in the legitimation and triumph of the power of Big Business, albeit in the guise of a "democratic transition." President Fox (2000-2006) described his government as a "government of entrepreneurs, by entrepreneurs and for entrepreneurs" (La Prensa, Panama, 21 June 2001). This transition to electoral competitiveness at the presidential level was a defeat for the ruling party and opened up a new political scene of constrained party competition in Mexico. The very real electoral space and democratic dynamics that were opened up were subordinated to the dynamic of the rise of more direct capitalist rule and increased repression by the state and private forces. The concentration of wealth and power through privatization and other government policies intensified bourgeois domination and both constrained and hollowed out the processes of democratization. When the tendencies to democratization challenge the boundaries of capitalist power, democratization is sacrificed for "stability."

The corporate offensive was the main driving force in the neoliberal transformation of Mexico as it was in the US and Canada. But in Mexico the corporate power bloc had to change the political order and aspects of the 
political culture in order to achieve its hegemonic aspirations and bring about its desired policy changes. It was joined in these goals by sections of the political elite who had moved away from Keynesian and statist ideas and by the influence and pressures from international actors promoting neoliberalism and free trade. The growth of the influence of neoliberal economics and its impact on Mexican government technocrats studying in the US as well as the leverage asserted by the IMF and US during various Mexican crisis moments was, of course, crucial in leading to the triumph of the neoliberal corporate offensive already underway in Mexico. But it is mistaken to see Mexico's turn to neoliberalism and free trade as simply a result of these external factors. This dependency explanation obscures the struggle for hegemony within the Mexican capitalist class and of that class over Mexican society. The structural and instrumental power of capital acting through its different fractions and varying combinations of exit and voice strategies (Hirschman 1970) at different times has been decisive. The restiveness of Mexican capital under Bonapartist capitalist development changed into hegemonic aspirations. The Mexican capitalist class had to transform the relationship between capital and the state in order to achieve its policy goals. As described above, the political elite that controlled the state had a great deal more autonomy than did the political elites of the US and Canada. The domestic bourgeoisie had much less structural or political power over state elites in Mexico. The interpenetration of the capitalist class with the state was much more limited in Mexico than in the rest of North America until recent decades. The ideology of the regime was "revolutionary nationalism," an ideology that posited the leading role of the state not only in economic development but also in maintaining an equilibrium between capital and labour. The big bourgeoisie was kept outside the official party in the one party state though labour and peasant organizations composed two of the three official sectors. The fractious ideological conflicts and differences in sectional-economic interests within the capitalist class were utilized as part of the government's strategy for keeping the Mexican bourgeoisie in its place in the economic sphere and outside politics. Business could not completely overcome its internal divisions over ideology, strategy and tactics or different policy interests (especially over trade and protection) but over time, a dominant if not completely ideologically hegemonic fraction developed, aided by government economic policies and favouritism in the process of privatization. But Big Business had also to fight for the legitimacy of business playing any political role whatsoever. 
The eventual success of peak business leadership in achieving dominance within business and the state was made possible not only by their own efforts but by a variety of internal and international political and economic developments (Concheiro Bórquez 1996). The big bourgeoisie and sections of the state have succeeded in imposing a neoliberal model of development, an increasing fusion and open partnership of Big Business and the state, and the transformation of the role of the state from that of fostering some degree of equilibrium between capital and labour to fostering the complete domination of big business over labour.

While Big Business has been able to reshape the state and public policy, it has not achieved ideological hegemony over the overwhelming majority of the popular classes for two main reasons. First of all, Big Business and the rival political party elites have been unable to develop an electoral process that could legitimate the political regime. The unexpected emergence of a third electoral force, populist and nationalist, in the 1988 presidential election, in the candidacy of Cuauhtemoc Cárdenas through the National Democratic Front (FDN), later to become the PRD (Partido de la Revolución Democrática / Party of the Democratic Revolution), disrupted the hopes of the bourgeoisie and political elites for the establishment of electoral alternation between the right-wing business party, the PAN, and the old state-party, the PRI, now neoliberal. Cárdenas won the elections but the PRI fraudulently stole them leading to massive protests. And once again, in the presidential elections of 2006, the party of the right, the party of alternation, the PAN stole the presidential elections from Andres Manuel López Obrador and the PRD, again leading to massive protests and disruptions in Congress during the inauguration ceremonies. Though electoral hopes persist among broad sectors of the population, the frauds of 1988 and 2006, one by each of the major parties linger in popular memory. The smell of fraud that existed during one-party rule has now continued in the so-called "democratic transition." The corrupt, one-party authoritarian presidentialist regime has been replaced by a corrupt, multiparty authoritarian political system.

Secondly, the regime's neoliberal policies have been devastating to the lives of the popular classes as will be discussed in the next section. These neoliberal policies have produced wide-scale and persistent, albeit fragmented, resistance from social, community, and indigenous movements throughout Mexico. The struggles of the popular social movements have deepened and widened the awareness of the linkages between neoliberalism and the hollowed out "democratic transition." The "democratic transition" has come packaged with a devastating attack on 
Socialist Studies / Études socialistes 7(1/2) Spring/Fall 2011: 238-258

the lives of ordinary people. The combination of the continuing fraudulent electoral processes, the relentless devastation of living standards, and persistent popular protests have produced an increasingly militarized repressive state and sullen, but potentially explosive discontent.

\section{The Neoliberal Offensive}

\section{Massive Privatization and Union Busting}

In order to achieve this gigantic transfer of wealth from some hands to others, the Mexican oligarchy and the transnational power groups carried out diverse political and financial operations to destroy the formerly powerful public sector of the economy, a sector that controlled many of the strategic branches, at the same time subordinating workers in all the spaces in dispute. Mexico's privatization program was one of the largest in the world. The number of state-owned enterprises decreased from 1155 in 1982 to 210 in 2003. The most important and profitable enterprises were sold at bargain-basement prices to powerful Mexican capitalists and/or politically well-connected people. Some of the important companies that were privatized were the national telephone company (Telmex), the national airline (Mexicana de Aviación), a national TV network (Televisión Azteca), several major steel plants (Siderúrgica Lázaro Cárdenas and Altos Hornos de México), a major ship-builder (Astilleros Unidos de Veracruz), the national railway (Ferrocarriles Nacionales de México) and many other companies. Article 27 of the Constitution was amended in 1992 to facilitate the break-up of ejidos (communally owned rural lands) as well as to grant mining companies longer and more generous rights to subsoil wealth. The mineral rights were transferred mainly to three Mexican companies: Peñoles, de Alberto Bailleres; Grupo México, de Jorge y Germán Larrea; y Carso, de Carlos Slim (who also received Telmex and is now, according to Forbes, the richest man in the world) (López Obrador 2010, 21-34).

Each privatization process produced a major conflict with the workers. The privatizations in the mining-metallurgical sector have resulted in a chronic conflict between the leading companies and the miners' union, over the continuing validity of the collective agreement. In the transport sector, the privatization of the railways and of the airlines continues to produce vicious attacks against union dissidents. The most recent case, the privatization of the electricity sector was only possible through the destruction of the union with the deepest roots and most democratic tradition in the country, the Mexican power workers union (SME; Roman and Velasco 2009). Perhaps the only exception in which 
ROMAN and ARREGUI: The Fragile Rise of Bourgeois Hegemony

privatization was not accompanied by a major conflict was in the case of Teléfonos de México, where the partnership approach of union and company allowed the union to "associate" itself in a dependent manner with the new owner, Carlos Slim.

The state policy of transferring public assets into private hands was accompanied by a fierce attempt to restore managerial control on the shop floor through various tactics from outsourcing, job flexibility and deregulation of labour relations on a constantly widening scale. The temporary or permanent closure of workplaces "contaminated" by trade union resistance, the dismantling of collective agreements, unilateral changes to labour law through case law issued by an increasingly conservative Supreme Court, and severe restrictions of the right to strike, the use of terror and intimidation to keep control in maquiladora cities of the North, have together and separately contributed to the cancellation of labour rights in many sectors of the economy, and even whole regions of the country, rights that Mexican workers had struggled to win in the ascendant phase of the Mexican Revolution.

\section{The Attack on Wages}

The consequences of neoliberalism for Mexican workers have been devastating. Real salaries have fallen dramatically from 1980 to 2010 in spite of great growth in productivity. The real value of the minimum wage declined by 70 percent from 1980 to 2010, the average of contracted wages in federal jurisdiction by over 50 percent, that of manufacturing by 20 percent. If we use pre-crisis (2007) figures, there's no change in the first two categories but average manufacturing wages had only fallen by 15 percent; they fell an additional 9 points between 2009 and 2010 (See table 1). According to official government sources, 44.2 percent of the population lived in poverty in 2008, over 47 million people (Consejo Nacional de Evaluación de la Política de Desarrollo Social n.d.). This figure has increased since the crisis of 2008 as jobs have been lost, more people forced into the lower-waged informal sector, and remittances from the US sharply reduced. The number of people in poverty in 2010 "had grown to 53 million, according to a study by the Monterrey Institute of Technology" (cited by Mexican Labour News and Analysis, January 2010).

We estimate that the share of the wages of production workers and nonsupervisory employees in the GDP declined from 35 percent in 1982 to 23 percent in 2009. This is consistent with the data on the evolution of the real minimum wage, of the average real contract wage among workers covered by federal jurisdiction and average wages in the manufacturing 
industry, according to the statistics presented in the Fourth Government Report by the Federal Executive of Mexico (Poder Ejecutivo Federal 2010, 189; see Table 1).

Table 1

Evolution of Real Salaries in Mexico in the Period 1980 to 2010 (1980 equals 100 percent)

\begin{tabular}{|c|c|c|c|}
\hline & $\begin{array}{l}\text { Minimum } \\
\text { Wage }\end{array}$ & $\begin{array}{c}\text { Average Contractual Wage in } \\
\text { Branches under Federal Jurisdiction }\end{array}$ & $\begin{array}{c}\text { Average Wages in } \\
\text { Manufacturing Industry }\end{array}$ \\
\hline 1980 & 100.00 & 100.00 & 100.00 \\
\hline 1985 & 68.13 & 78.39 & 96.56 \\
\hline 1990 & 49.30 & 63.63 & 78.39 \\
\hline 1991 & 46.53 & 64.32 & 83.04 \\
\hline 1992 & 41.85 & 62.37 & 90.13 \\
\hline 1993 & 42.10 & 62.35 & 85.14 \\
\hline 1994 & 41.66 & 61.37 & 88.64 \\
\hline 1995 & 35.11 & 51.05 & 77.26 \\
\hline 1996 & 36.05 & 45.97 & 69.92 \\
\hline 1997 & 31.80 & 45.54 & 69.46 \\
\hline 1998 & 34.56 & 46.24 & 71.47 \\
\hline 1999 & 31.32 & 46.20 & 72.49 \\
\hline 2000 & 31.51 & 47.43 & 76.81 \\
\hline 2001 & 32.03 & 48.65 & 81.88 \\
\hline 2002 & 32.06 & 49.01 & 83.41 \\
\hline 2003 & 32.14 & 49.10 & 84.51 \\
\hline 2004 & 31.44 & 48.84 & 84.70 \\
\hline 2005 & 31.79 & 49.02 & 84.06 \\
\hline 2006 & 31.52 & 49.25 & 84.73 \\
\hline 2007 & 31.41 & 49.43 & 85.33 \\
\hline 2008 & 30.23 & 49.04 & 86.43 \\
\hline 2009 & 30.53 & 48.62 & 86.27 \\
\hline 2010 & 30.32 & 46.83 & 79.50 \\
\hline
\end{tabular}

Poder Ejecutivo Federal 2010.

We can get a better handle on the significance of this fall of the share of wages in the GDP of Mexico if we put it in comparative context in terms of the cost of living and real purchasing power parities in the economies of various countries. The relative level of wages in Mexico has been steadily declining in the last quarter century. The report by the Union Banks of Switzerland, Price and Earnings around the Globe (Union Banks of Switzerland 2009, 9) shows that wages in Mexico City are among the 
ROMAN and ARREGUI: The Fragile Rise of Bourgeois Hegemony

lowest of the 60 most important cities in the world. In 2009, average wages in Mexico City were fifteen times lower than the New York City, eleven times lower than those of Chicago, eight times less than those of Montreal, four times less than Seoul, three times less than Sao Paulo and two times less than those of Santiago de Chile. This report shows that the view that the People's Republic of China has lower wages than Mexico is false. The salaries of Shanghai or Beijing were more than double that of Mexico City in 2009.

This situation has deteriorated further in recent decades. It was not just a result of the economic disasters of the eighties. Since 1994, the relative situation of wages in Mexico has deteriorated, even in the period of alleged fiscal responsibility and equilibrium. In 1994, according to the same report, Price and Earnings around the Globe, Mexican wages were much closer to the main cities of the world. Wages in New York and Chicago were just five times higher than Mexico City; those of Montreal were slightly more than four times that of Mexico City. In almost all cases the distance was half of what it is now. Wages in Seoul were only two times higher than Mexico City and those of Sao Paulo, Brazil were even below those of Mexico City. The problem of low wages is the central source of poverty in Mexico, as the official unemployment rate is only 6.2 percent. In Mexico, the vast majority of people are poor because they receive low wages, not because they're not working.

\section{The Attack on Unions}

There have been great ebbs and flows in union membership in Mexico over the last century in relation to the level of class struggle and the policies of the government. The Revolution produced powerful institutional mechanisms that gave great power to the government to facilitate or obstruct union formation. These powers, based on article 123 of the Constitution of 1917 and implemented in subsequent labour legislation allowed the government to declare strikes legitimate or illegitimate as well as to grant or deny union recognition. Unions had to walk a difficult tightrope between independence and currying the favour of the ruling party to survive. As unions, especially their leadership, became integrated into the ruling party when it was formed in the late 1930s, it provided them a means of influencing government labour policy and a powerful push towards becoming part of the state system of labour control. As the government's policies turned more to the right in the 1940s and beyond, union officialdom became a more and more privileged state-linked disciplining oligarchy over its own members. There have been and 
continue to be bitter struggles between rank and file members and their official leaders, charros, over control of unions. Further, the decadence of this stratum of charros has extended to the sale of protection contracts and the creation of phantom unions, "unions" in name only, selling contracts to management to prevent the formation of real unions and often not even known to their own members. Further, many of the unions in the industrial region around Monterrey, Nuevo León, are white or company unions set up by the region's extremely right-wing capitalists to keep out real or charro unions. There are, then, two sets of "unions" that are not unions, the phantom and the white unions. Charro unions have a greater heterogeneity and their union-like character will vary by union and period, depending on rank and file pressures, political considerations of the charro leaderships, and relationship to management. Some engage in real bargaining for their members, others are completely in bed with management. This fictional and semi-fictional character of most Mexican unions makes it necessary to approach union density figures in Mexico with great caution.

Nevertheless, it's clear that there has been a real decline in union membership in the last decades, The Commission for Labour Cooperation of NAFTA has shown that the rate of unionization in Mexico declined by 25 percent from the end of the 1980s to 2003, when it became less than 15 percent (North American Agreement on Labour Cooperation (NAALC) $2003,25)$. The crisis of the public sector and the reclassification of more and more workers as employees of confidence not eligible for union membership had a big impact on union membership. The recent recession has also taken a toll on union membership. According to the official statistics of the Commission for Labour Cooperation, scarcely 4 million workers out of an economically active population of 43 million are members of unions. If you were to peel away the completely fictional unions (phantom unions), those with protection contracts, the number of union members would be greatly reduced. It's estimated that at least 85 percent of Mexican workers have protection contracts, fake contracts signed by corrupt union officials to exclude genuine unions (Xelhuantzi López, et al. 2005, 151). Of the remaining 15 percent, most are members of charro unions, corrupt, authoritarian, quasi-corporatist, governmentlinked unions. Thus most of the working class has continued to lack organizations through which to build effective fight backs against the relentless neoliberal assault that has devastated living standards, workplace health and safety, and workers' rights in general.

The estimate of 15 percent is based on non-rural workers (private and public), excluding those in small familial artisanal shops. The rural 
ROMAN and ARREGUI: The Fragile Rise of Bourgeois Hegemony

sector, which includes only 15 percent of the economically active population, only has a unionization rate of 4 percent. If we take into account the whole labour force of the country, including the proletarianized or semi-proletarianized rural sectors (including miniproducers and ejidatarios, who often also work as seasonal or day labourers within Mexico or the US), the rate of unionization decreases to 11 percent, which would give Mexico the lowest rate of unionization of the three NAFTA countries (INEGI 2009).

The principal consequence of the corporate offensive has been the extreme pauperization of workers and campesinos, with the exception of small segments that preserved some elements of economic well-being as is the case with the oil workers, the telephone workers, and until 2009, the power workers of the Light and Power Company of the Centre (Luz y Fuerza del Centro). In 2009, all 45,000 power workers were fired and the company liquidated. But for the immense majority of workers in Mexico, the profound deterioration of the purchasing power of wages is a significant and defining characteristic under the new capitalist despotism. In other parts of Latin America, the imposition of such a catastrophic salary decline was only possible through the use of the coercive force of military coups suffered by the region starting with the military coup in Brazil in 1964.

\section{Unemployment}

Neoliberal policies have completely failed to provide new formal sector jobs for Mexico's rapidly growing labour force. Mexico has only been creating about 12 percent of the new jobs needed for the 2 million young people entering the labour market each year. Only 2.2 million new jobs have been created in the formal sector of the Mexico economy between 2000 and 2010 while 20 million people have joined the labour market (IMSS 2010a). These figures would have to be modified by taking into account the opening up of already existing jobs through retirement. Nevertheless, the job deficit is enormous. Neoliberal policies, by opening the economy to cheap imports and removing subsidies, have caused a massive loss of sources of livelihood in those parts of the rural sector that produce for the domestic market. The same effects have been felt in industries oriented to the domestic market. But these losses have not been offset by the creation of new jobs. The lack of significant job creation coupled with the destruction of jobs and rural livelihoods has fuelled massive emigration from Mexico. Mexico is a gigantic factory for producing pauperized workers. Every day, approximately 6,000 young people enter a 
labour market that creates only slightly more than 700 spaces daily. The tremendous number of undocumented young people who try to cross the border daily are only a small portion of the millions of dispossessed youth whose hopes for the future have been destroyed by the neoliberal project.

On the other hand, the informal sector, far from being a space of self-employed workers, marks a return to the most intense forms of exploitation within "small establishments": in 1995, the number of wage earners within the informal sector was 2.8 million and accounted for 32 percent of informal employment. By 2003, wage earners in the informal sector accounted for 4.3 million workers, 40 percent of those working in the underground economy, those companies that operate without any official registration. In the labour market as a whole, formal and informal, 27 million workers work in establishments of less than 11 workers. There are 600,000 "protection contracts" in this sector of small workplaces. Only three percent of the 27 million workers in small establishments are formally unionized (Xelhuantzi López, et al. 2005, 40).

The present crisis has had a devastating impact on this already vulnerable labour force, of which approximately two-thirds, or 32 million people, remain ensnared in the informal labour market, in a situation of desperation and hopelessness, and only one-third, 17 million, are part of the formal labour market. In reality, the number of people, that exist in the interstices of the economic life of the country, without even gaining a minimum wage (which, at present, is less than 60 pesos daily or less than \$5 US daily), has reached ten million people.

There has been renewed job growth in the Mexican economy since the crisis of 2009 with an increase of 714,000 jobs in the formal sector from January 2009 to January 2011. However 64 percent of these new jobs are at the lowest end of the pay scale, between one and two minimum salaries (between $\$ 5$ and $\$ 10$ US daily) (IMSS 2010b). The transfer of jobs from the US and Canada has continued through the crisis but at rockbottom wage levels. Government austerity since the crisis has focused on cutting subsidies to gas and hydro leading to price increases of 12 percent for gas and 15 percent for hydro in the last year. These price increases have contributed to the high general inflation of wage goods in Mexico.

\section{Towards a Fightback: Mexico and the Struggle for Workers' Rights in North America}

The Mexican bourgeoisie has succeeded in defeating and dismantling the economic and political basis of power of the old party-state elites. They have also succeeded in imposing decades of austerity on the Mexican 
ROMAN and ARREGUI: The Fragile Rise of Bourgeois Hegemony

people. But they have not been able to consolidate a solid historical bloc, a system in which competition and conflict could be contained by a hegemonic consensus among the key political and economic elites. As well, the concurrent neoliberal assault on the mass of the population has combined with the on-going corruption and electoral fraud to undermine attempts at legitimating the new regime to the mass of the population. Mexico's organic crisis, simmering in the last decades of the old regime, has come close to boiling over several times in the post-old regime period (since 2000) as in the anti-electoral fraud protests of 2006 and in the Oaxaca uprising that same year (Roman and Velasco 2008).

The struggle of Mexican workers is taking place in this context of an organic crisis, growing militarization and repression, the continuation of the neoliberal assault on popular rights and wellbeing, and a likely prolonged economic recession. It is not taking place in a context of a democratic regime or an actual democratic transition. Though Mexico's "democratic transition" was fuelled by the democratic aspirations of the middle classes, working class, and popular sectors, it has been largely captured by the bourgeoisie seeking more direct control of the Mexican state. The vast majority of the population has experienced the "democratic transition" with great disappointment, though many still hope to push it back on a democratic path. But they face political and economic elites who, in spite of their conflicts, are willing to use ruthless repression against any popular challenges to their power and privilege.

The working class movement is at a nadir of resistance. The ongoing state repression of unions (the defeat and dismantling of the SME, the relentless assault on the miners' union) and of popular movements (Atenco, Oaxaca, the permanent war of attrition against the Zapatistas), the continuing state-facilitated thuggery of the officials of major unions against their own members (the national teachers union is a leading example), the job losses of Mexican workers on both sides of the border, and the absence of a direction of struggle that seems promising, have all contributed to a demoralization of the working class generally and of working class militants. People are scrambling to survive without the existence of obvious collective ways of fighting back.

Nevertheless there are significant factors that point to the possibility of a revival, sooner rather than later, of a fight back on the part of the working class. Mexico's popular revolutionary tradition lives on in both working class and in peasant and indigenous communities. As well, the communalist traditions of Mexico's peasants and indigenous peoples have migrated along with these peasants and indigenous peoples in their 
decades of proletarianization and urbanization. These traditions survive in urban as well as rural areas (which now contain less than 25 percent of the population).

If these powerful and widely spread residues of revolutionary tradition and communalist sensibility have a wide presence in the popular classes, the relentless character of Mexico's neoliberal capitalist offensive will increasingly compel people to seek collective solutions. The hopes for better jobs, more rights, and a more civil country raised by the decades of struggle for a democratic transition, by the false promises of NAFTA making Mexico a first-world country, by the replacement of the one-party regime in the presidential elections of 2000 , have been demolished by the realities of the relentless neoliberal assault and the new austerity being imposed on the popular classes by the regime. A large majority of Mexico's population lives in extreme poverty; many are being pushed over the edge of survival by the recent crisis which, in Mexico, has been combined with rising food and utility prices. The US economic crisis has both closed the safety valve of the US labour market for "surplus" Mexican workers and dramatically reduced remittances to Mexico, a key source of survival for many families and communities. There are no indications of an economic revival on the horizon as Mexico's dependence on the US economy guarantees that Mexico's recovery will be as slow as that of the US. The government of Mexico is carrying out austerity programs that will both make life harsher for workers and the poor and make a recovery more difficult.

The new Mexican workers' movement cannot develop on the basis of trade unionism alone. Workers will continue to face severe and brutal repression by the state, private capital, and charros. The new movement will have to challenge the very framework and institutions of repression. Union and workers' rights can only achieve any durability in a transformed institutional framework. The fight for reformist goals and democratic demands (right of association, civil liberties, etc.) have to be blended with strategies in which workers prepare themselves ideologically and organizationally for a transformational struggle.

The struggle of Mexican workers has powerful continental dimensions. Mexico is part of NAFTA along with its two northern neighbours. US and Canadian companies, especially auto and auto parts, have major investments in Mexico. And the Mexican working class has a powerful presence in the US labour force. Around one-fifth of the Mexican working class works in the US and Mexicans make up the largest segment of the immigrant section of the US working class. This means that events in 
ROMAN and ARREGUI: The Fragile Rise of Bourgeois Hegemony

the Mexican class struggle will resound powerfully in the US (with echoes in Canada).

Worker's insurgency in Mexico will immediately trigger hostile responses from US and Canadian capital as well as their governments. Mexican workers will need solidarity from the North to oppose open or disguised military intervention, an intervention whose foundations have been set already with Plan Mexico (security and military cooperation agreement between the US and Mexico). But beyond this essential antiinterventionist solidarity, there needs to develop a strategy of common struggles over related though not identical demands around social justice, workers' rights, and genuine democracy.

Continental integration of North America, especially through NAFTA, has afforded US and Canadian, as well as Mexican, capital powerful levers for downward pressures on the whole North American working class, including the Mexican. But it has also added an explosive ingredient to the North American panorama of class struggle: a young, superexploited working class with old revolutionary and communalist traditions in a ruthless regime in deep and multiple crises. When Mexico's working class jaguar rises, the roar will resonate deep into the North.

\section{References}

Concheiro Bórquez. 1996. El Gran Acuerdo: Gobierno y empresarios en la modernización salinista. México: Universidad Nacional Autónoma de México.

Consejo Nacional de Evaluación de la Política de Desarrollo Social. n.d. "Evolucion de la Pobreza por Ingresos a Nivel Nacional."

http://medusa.coneval.gob.mx/cmsconeval/rw/pages/medicion/cifras/pobrezapo ringresos.es.do.

Cypher, James M. 1990. State and Capital in Mexico. Boulder: Westview.

Cypher, James M and Raúl Delgado Wise 2010. Mexico's Economic Dilemma: The Developmental Failure of Neoliberalism. Lanham: Rowman and Littlefield.

Hirschman, Albert 0. 1970. Exit, Voice and Loyalty. Cambridge, MA: Harvard University Press.

Instituto Mexicano del Seguro Social (IMSS). 2010a. Memoria estadística del IMSS. Capítulo Evolución del Empleo. Mexico: Insituto Mexicano del Seguro Social.

Instituto Mexicano del Seguro Social (IMSS). 2010b. Memoria estadística del IMSS, Insituto Mexicano del Seguro Social, 2010, Capítulo Evolución de los trabajadores cotizantes por Nivel de Ingreso. México, 2010b.

Instituto Nacional de Estadística y Geografía (INEGI). 2009. Encuesta Nacional de Ingreso Gasto de los Hogares 2008 Ampliada Cuadro XX Característica de los Ingresos por Rubro. Mexico. Instituto Nacional de Estadística y Geografía. 
La Prensa, Panama, 21 June 2001.

López Obrador, Andrés Manuel. 2010. La Mafia que se adueño de México y el 2012. México. Editorial Grijalva.

Marois, Thomas. 2008. "The 1982 Mexican Bank Statization and the Unintended Consequences for the Emergence of Neoliberalism." Canadian Journal of Political Science 41, no. 1: 143-167.

North American Agreement on Labor Cooperation (NAALC) - Washington Office. 2003. North American Labor Markets, Main Changes Since NAFTA.

Poder Ejecutivo Federal. 2010. IV Informe de Gobierno. México: Gobierno de México.

Puga, Cristina. 2004. Los empresarios organizados y el Tratado de Libre Comercio de América del Norte. México. Universidad Nacional Autónoma de México.

Roman, Richard and Edur Velasco Arregui. 2007. "Mexico's Oaxaca Commune” in Socialist Register 2008: Global Flashpoints: Reactions to Imperialism and Neoliberalism, ed. Leo Panitch and Colin Leys, 248-264. London: Merlin Press.

Roman, Richard and Edur Velasco Arregui. 2009. "Mexico: The Murder of a Union and the Rebirth of Class Struggle, Part I: The New Assault," The Bullet 279, 25 November 2009, http://www.socialistproject.ca/bullet/279.php; "Part II: The Fightback," The Bullet 280, 26 November 2009, http://www.socialistproject.ca/bullet/280.php.

Schneider, Ben Ross. 2002. "Why is Mexican Business So Organized?" Latin American Research Review 37, no. 1: 77-118.

Thacker, Strom C. 2000. Big Business, the State and Free Trade: Constructing Coalitions in Mexico. Cambridge: Cambridge University Press.

Union Banks of Switzerland (UBS). 2009. Price and Earnings around the globe: $a$ comparison of purchasing power around the globe. Zurich: UBS.

Xelhuantzi López, María et al. 2005. Auge y Perspectivas de los Contratos de Proteccion. México: Fundación Friederich Ebert. 